\title{
Representasi Perempuan dalam Film Dangal Karya Disney dan Aamir Khan Productions
}

\author{
Myesha Adira, Wulan Purnama Sari \\ myeshadira2312@gmail.com,wulanp@fikom.untar.ac.id \\ Fakultas Ilmu Komunikasi Universitas Tarumanagara
}

\begin{abstract}
Dangal is a family movie with a sports-themed drama genre produced by Walt Disney Pictures and Aamir Khan Productions by director Nitesh Tiwari. The film, which is based on this true story, tells the story of two Indian sisters named Geeta and Babita, who experience an unnatural life like most of women. Geeta and Babita were deliberately trained by their father to become wrestling athletes so they would be able to fly Indian country's flag in the Olympic championship, where wrestling is very well known in India. This film is different from previous Disney films, because the film portrays the role of women taking roles which previously were dominated by men in the field of wrestling. This study aims to find out how the representation of women in the film. In analyzing this film, the method used is semiotics by Roland Barthes, which divides into denotations, connotations and myths. The results of the study indicate a shift in the portrayal of women as strong and courageous characters, women with feminine attitudes are able to compete with men.
\end{abstract}

Keywords: Representation, Women, Film, Semiotics

\begin{abstract}
Abstrak
Dangal merupakan film keluarga dengan genre drama bertemakan olahraga yang diproduksi oleh Walt Disney Pictures dan Aamir Khan Productions karya sutradara Nitesh Tiwari. Film yang diangkat dari kisah nyata ini, menceritakan tentang dua orang kakak beradik perempuan asal India bernama Geeta dan Babita, yang mengalami kehidupan tidak sewajarnya seperti perempuan kebanyakan. Geeta dan Babita sengaja dilatih oleh sang ayah menjadi atlet gulat untuk dapat mengibarkan bedera negaranya dalam ajang kejuaraan olimpiade, yang mana olahraga gulat sangat terkenal di India. Film ini berbeda dari film-film Disney terdahulu, karena dalam film Dangal ini menggambarkan perempuan mengambil peran yang sebelumnya didominasi oleh laki-laki dalam bidang gulat. Penelitian ini bertujuan untuk mengetahui bagaimana representasi perempuan di dalam film tersebut. Dalam menganalisis film ini, metode yang digunakan yaitu semiotika yang dipelopori oleh Roland Barthes, yang membagi ke dalam denotasi, konotasi dan mitos. Hasil penelitian menunjukkan adanya pergeseran penggambaran perempuan sebagai karakter yang kuat dan berani, perempuan dengan sikap feminime mampu untuk bersaing dengan laki-laki.
\end{abstract}

Kata Kunci: Representasi, Perempuan, Film, Semiotika

\section{Pendahuluan}

Komunikasi merupakan suatu hal yang sangat mendasar dalam kehidupan manusia, bahkan komunikasi telah menjadi suatu fenomena bagi terbentuknya suatu masyarakat terintegrasi oleh informasi, dimana masing-masing individu di dalam masyarakat itu sendiri saling berbagi informasi untuk mencapai tujuan bersama (Rohim, 2016). Untuk mempermudah proses komunikasi kepada khalayak yang lebih luas, berkembanglah komunikasi massa. 
Menurut Bitner (dalam Riswandi, 2009), komunikasi massa adalah pesan yang dikomunikasikan melalui media massa pada sejumlah besar orang. Batasan komunikasi massa ini lebih menitikberatkan pada komponen-komponen dari komunikasi massa yang mencakup pesan-pesan dan media massa, serta khalayak. Bentuk media massa yang menjadi bentuk komunikasi massa visual salah satunya film.

Film saat ini menjadi salah satu cara efektif dalam menyampaikan informasi atau pesan. Kemampuan film menjangkau banyak segmen sosial, membuat film memiliki potensi untuk mempengharuhi khalayaknya. Perkembangan film sampai saat ini mempunyai beberapa jenis, salah satunya adalah film cerita. Film cerita yaitu film yang di dalamnya terdapat atau dibangun dengan sebuah cerita. Film cerita dari hasil realita maupun imajinasi sangat membantu publik untuk melihat peristiwa yang sedang terjadi (Romli, 2016).

Menurut Turner (dalam Sobur, 2013), makna film sebagai representasi dari realitas masyarakat, berbeda dengan film sekedar sebagai refleksi dari realitas. Sebagai representasi dari realitas, film membentuk dan "menghadirkan kembali" realitas berdasarkan kode-kode, konvensi, dan ideologi dari kebudayaannya. Nuraini Julianti memaparkan (dalam Wibowo, 2011), representasi bekerja pada hubungan tanda dan makna. Konsep representasi sendiri berubah-ubah. Selalu ada pemaknaan baru.

Walt Disney dikenal dengan film-filmnya yang menginspirasi dan memiliki pesan yang positif, baik animasi maupun yang diangkat dari kisah nyata. Sebelumnya, film-film Disney yang bertema olahraga seperti Remember the Titans, The Rookie, Miracle, dan Million Dollar Arm, memiliki beberapa kesamaan. Film-film tersebut diangkat dari kisah nyata dan bertokoh utamakan laki-laki. Pada tahun 2016 Disney kembali merilis film bertema olahraga yang juga diangkat dari kisah nyata berjudul Dangal. Film ini diproduksi Disney bersama Aamir Khan Productions.

Ada sesuatu yang baru dari Disney mengenai film Dangal ini. Keunikan dari film Dangal yaitu berbeda dengan film-film Disney sebelumnya adalah tokoh utamanya adalah perempuan. Film Dangal sendiri bercerita tentang seorang pegulat di India bernama Mahavir Singh yang melatih putri-putrinya yaitu Geeta dan Babita, untuk menjadi pegulat kelas dunia. Perjuangan yang dilalui Geeta dan Babita sangat berat karena gulat sendiri bukan olahraga yang umum digeluti perempuan mengingat budaya patriarki yang mengakar di India (diakses dari https://www.voaindonesia.com/a/gulat-putri-ubah-paradigma-sosialindia/3709055.html, pada 3 September 2018 pukul 05.15 WIB).

Alasan penulis memilih film Dangal karena terdapat nilai representasi perempuan yang terletak pada tokoh dalam film yaitu, Geeta dan Babita. Penambahan tokoh perempuan dan menjadikan perempuan sebagai tokoh utama menjadi topik dalam penelitian ini. Dalam film, perempuan digambarkan sebagai sosok yang berani, kuat, tangguh, dan mandiri. Tidak seperti perempuan pada umumnya yang bermain atau membantu pekerjaan rumah, sejak kecil, Geeta dan Babita dilatih menjadi pegulat. Terlepas dari itu, ada pula unsur-usur patriarki dan nasionalisme yang terkandung dalam film ini. Diperlihatkan juga bahwa para perempuan ini mampu untuk bersaing dengan laki-laki dalam hal olahraga gulat.

Berdasarkan uraian dan fakta diatas penulis tertarik untuk melakukan penelitian mengenai bagaimana representasi perempuan yang terdapat pada tokoh Geeta dan Babita dalam film Dangal. Tujuan dari penelitian ini untuk mengetahui tanda-tanda yang merepresentasikan perempuan pada film Dangal. 
Myesha Adira, Wulan Purnama Sari: Representasi Perempuan dalam Film Dangal Karya Disney dan Aamir Khan Productions

\section{Metode Penelitian}

Dalam penelitian ini, pendekatan yang digunakan adalah kualitatif. Dalam menganalisis film ini, analisis semiotika digunakan sebagai strategi penelitian. Subyek dari penelitian ini yaitu film Dangal itu sendiri yang dikemas dalam bentuk DVD Bluray. Obyek dari penelitian ini yaitu gambaran perempuan yang direpresentasikan oleh para tokoh utama perempuan di film Dangal, yaitu melalui tokoh Geeta dan Babita.

Sumber data dalam penelitian ini berupa adegan-adegan yang tersirat tanda atau simbol yang merepresentasikan perempuan di dalam film Dangal. Data tersebut diperoleh melalui film Dangal yang berdurasi 02:41:01 dan buku referensi, artikel, serta penelusuran data melalu media online/internet. Metode yang digunakan untuk mengumpulkan data yang digunakan penulis adalah dengan observasi.

Teknik pengolahan analisa data yang digunakan dalam penelitian ini adalah analisis semiotika model Roland Barthes untuk menginterpretasikan makna yang terkandung dalam gambar-gambar serta kalimat yang ada dalam film Dangal. Dalam semiotika Roland Barthes, data dibagi ke dalam denotasi, konotasi dan mitos. Untuk pengabsahan data, penulis menggunakan teknik pengecekan triangulasi.

\section{Hasil Temuan dan Diskusi}

Representasi perempuan yang terdapat film Dangal dapat dijabarkan dengan menggunakan analisis semiotika model Roland Barthes dengan membagi data menjadi denotasi, konotasi, dan mitos. Berikut analisinya:

Tabel 4.1 Analisis Semiotika Film Dangal ke-1

\section{Gambar 4.1 Sosok Ibu Rumah Tangga}

Durasi ke: 15:00, 19:23, 19:00 dan 22:31

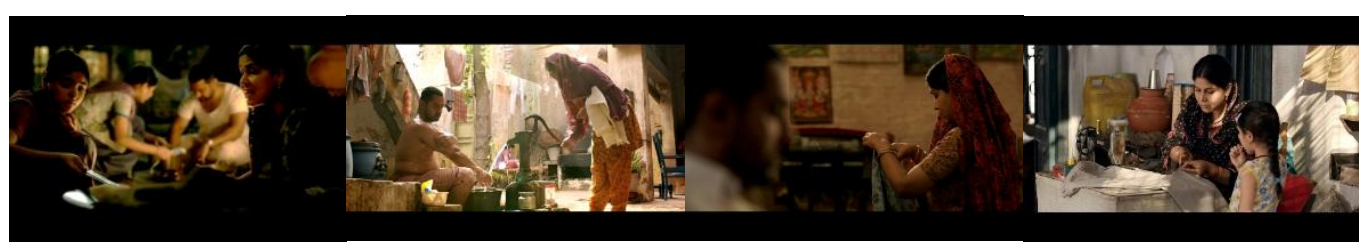

Signifier

Gambar menampilkan seorang wanita dewasa, pria, dan juga anak-anak. Pada gambar terlihat sosok wanita yang sedang melakukan beberapa aktivitas, diantaranya yaitu memasak, menimba air, merapikan pakaian, dan menjahit. Terdapat pula anak perempuan yang sedang membantu sang wanita

Tingkat memasak. Sedangkan sang pria terlihat sedang menyantap makanan dan Pertama mandi.

(Denotasi)

\section{Signified}

Menunjukkan bahwa karakter-karakter tersbut merupakan sebuah keluarga. Sosok wanita dewasa adalah ibu/istri yang sedang melakukan pekerjaan rumah tangga yang biasa dilakukan oleh para ibu rumah tangga. Sedangkan sosok pria adalah ayah yang menikmati hasil pekerjaan dari sosok ibu/istri.

\section{Signifier}

Tingkat

Kedua

(Konotasi)

Menunjukkan bahwa karakter-karakter tersbut merupakan sebuah keluarga. Sosok wanita dewasa adalah ibu/istri yang sedang melakukan pekerjaan rumah tangga yang biasa dilakukan oleh para ibu rumah tangga. Sedangkan sosok pria adalah ayah yang menikmati hasil pekerjaan dari sosok ibu/istri. 
1. Istri/ibu bertugas mengurus semua pekerjaan dirumah.

2. Istri berbakti kepada suami.

3. Ibu rumah tangga tidak bekerja diluar rumah.

4. Melakukan pekerjaan rumah tangga merupakan tanggung jawab seorang istri/ibu.

Mitos Perempuan telah terkonstruksi bahwa tugas utamanya adalah

Mitos mengelola rumah tangga. Pekerjaan perempuan yang lebih fokus kepada ranah domestik membentuk anggapan dan penilaian bahwa pekerjaan istri diluar rumah (yang berkarir) menjadi beban ganda (Utaminingsih, 2017: 23).

Pada adegan di atas, menunjukkan perempuan di India yang telah menikah dan berkeluarga. Dalam film, wanita di India yang telah menjadi istri/ibu, bertanggungjawab untuk mengurus segala pekerjaan rumah tangga. Hal ini relevan dengan pengertian Dr. Dra. Alifiulahtin Utaminingsih M, Si. yaitu, perempuan telah terkonstruksi bahwa tugas utamanya adalah mengelola rumah tangga. Ibu dan istri di India, digambarkan sepenuhnya beraktivitas didalam rumah.

Tabel 4.2 Analisis Semiotika Film Dangal ke-2

\section{Gambar 4.2}

Perempuan Dilatih Menjadi Pegulat

Durasi: 23:30, 26:20, 37:22, dan 37:50.

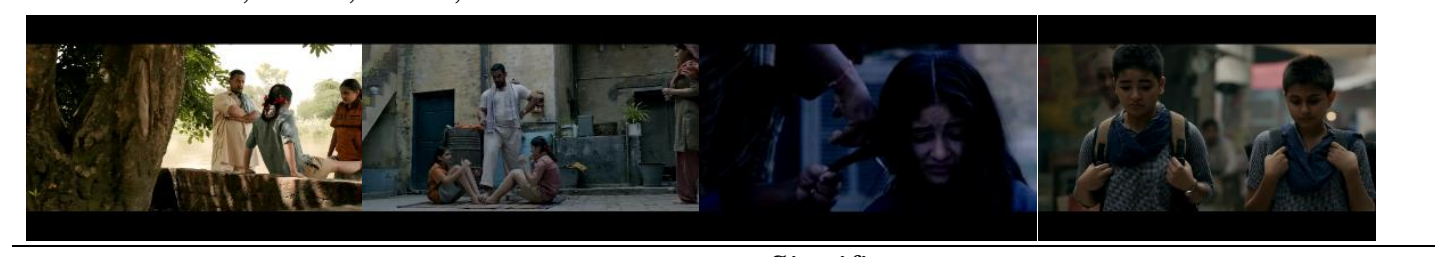

Signifier

Gambar menampilkan seorang laki-laki dan dua orang anak perempuan. Sang laki-laki terlihat sedang melatih anak-anak perempuan. Ditampilkan juga gambar salah satu anak perempuan yang rambutnya dipotong pendek,

Tingkat sang anak terlihat menangis ketika rambutnya dipotong. Gambar setelahnya

Pertama menampilkan kedua anak perempuan tersebut berjalan menggunakan

(Denotasi) seragam sekolah, jadi berambut pendek dan terlihat seperti anak laki-laki.

\section{Signified}

Menunjukkan bahwa anak perempuan di India patuh kepada perintah sang ayah. Anak perempuan menjalani latihan yang diperintahkan dan terpaksa harus memotong pendek rambut mereka.

\section{Signifier}

Menunjukkan bahwa anak perempuan di India patuh kepada perintah sang ayah. Anak perempuan menjalani latihan yang diperintahkan dan terpaksa harus memotong pendek rambut mereka.

Tingkat Signified

Kedua

(Konotasi)

1. Ayah merupakan kepala keluarga, sehingga anggota keluarga termasuk anak harus patuh kepada ayah.

2. Ayah sebagai kepala keluarga, berhak untuk mengambil dan menentukan segala keputusan.

3. Sistem keluarga di India yang patrialkal.

4. Anak perempuan harus berbakti dan harus menghormati orang tua.

5. Anak perempuan akan mendapat hukuman jika tidak patuh.

1. Asnika Simanjuntak mengutip dari Sudarwati (2011) (dalam Basri, 2018:

Mitos 16), bahwa Sistem Patriakat adalah kekuasaan berada di tangan ayah atau pihak laki-laki. Dalam nilai patriakat, kedudukan laki-laki ditempatkan lebih 
tinggi dari perempuan dalam aspek kehidupan. Perempuan dianggap sebagai sub-ordinat laki-laki dan masih dimarginalkan. Kedudukan seperti ini menyebabkan otoritas mengambil keputusan berada di tangan laki-laki.

2. India merupakan negara yang menganut sistem sosial Patriarki dimana status sosial laki-laki memiliki derajat yang lebih tinggi dibandingkan perempuan. India sangat menjunjung tinggi harkat laki-laki jauh diatas perempuan yang mengakibatkan munculnya kesenjangan gender antara lakilaki dan perempuan di India. Kesenjangan sosial tersebut meliputi permasalahan pendidikan, kesehatan, kehidupan rumah tangga, status sosial, pernikahan di usia muda, serta kemandirian perekonomian (diakses dari https://kumparan.com/nazar-el-mahfudzi/humanitarisme-kehidupan-sosialperempuan-di-india-tahun-2013-2015, pada 12 Desember 2018 pukul 10:42 WIB).

Adegan di atas menunjukkan perempuan di India yang dilatih menjadi pegulat sejak anak-anak. Dalam film, diperlihatkan bahwa proses dari anak-anak perempuan untuk menjadi pegulat tidaklah mudah. Berawal ketika para karakter (Geeta dan Babita) menjalani latihan gulat karena merupakan perintah dari sang ayah (Mahavir), bukan keinginan dari hati mereka. Bahkan, anak perempuan diperintahkan oleh sang ayah untuk berpakaian seperti anak laki-laki sampai memangkas habis rambut mereka demi gulat. Hal ini relevan dengan patriarki yang mengakar di India. Didukung dengan teori yang dipaparkan Sudarwati yang dikutip oleh Simanjuntak (2018), dimana Sistem Patriakat adalah kekuasaan berada di tangan ayah atau pihak laki-laki, yang membuat kedudukan laki-laki ditempatkan lebih tinggi dari perempuan dalam aspek kehidupan.

Tabel 4.3 Analisis Semiotika Film Dangal ke-3

Gambar 4.3 Perempuan Bergulat dengan Pria

Durasi: 53:50, 57:22, 58:13, dan 57:55

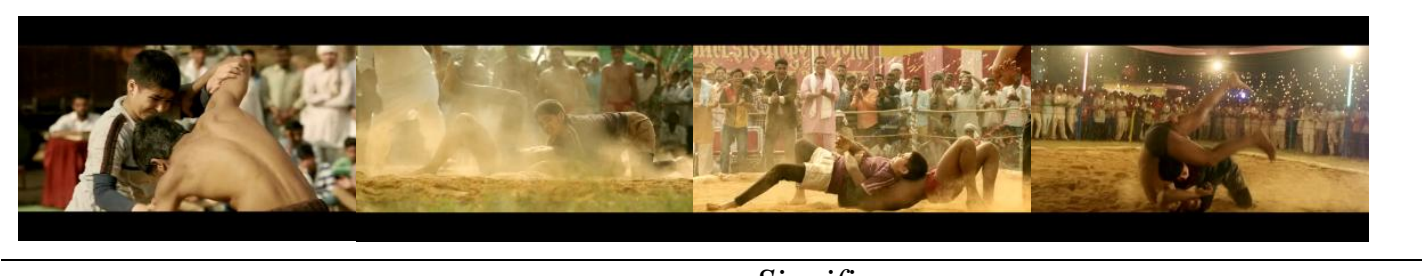

Signifier

Gambar menampilkan seorang anak perempuan yang berambut pendek, berpakaian seperti anak laki-laki, dan seorang anak laki-laki yang berbadan kekar yang hanya mengenakan celana untuk gulat. Dalam gambar terlihat

Tingkat anak perempuan sedang bergulat melawan anak laki-laki tersebut. Anak Pertama perempuan terlihat memberikan perlawanan yang baik karena mampu (Denotasi) menjatuhan badan lawan.

\section{Signified}

Menunjukkan bahwa perempuan bisa dan mampu melakukan olahraga gulat yang mayoritas dilakukan oleh laki-laki. Perempuan mampu bersaing melawan laki-laki dalam bergulat.

\section{Signifier}

Tingkat Menunjukkan bahwa perempuan bisa dan mampu melakukan olahraga gulat

Kedua yang mayoritas dilakukan oleh laki-laki. Perempuan mampu bersaing (Konotasi) melawan laki-laki dalam bergulat. 
1. Perempuan melakukan olahraga gulat yang mayoritas dilakukan laki-laki atau pria.

2. Perempuan memiliki kekuatan yang setara dengan laki-laki.

3. Perempuan bertanding gulat melawan laki-laki.

Steven memaparkan (dalam Basri, 2018: 38), pada zaman ini, peran perempuan dapat disetarakan dengan laki-laki. Perempuan tidak lagi dilihat pekerjaannya sebagai ibu rumah tangga saja. Mereka mempunyai fungsi

Mitos ganda, yakni sebagai ibu rumah tangga sekaligus wanita pekerja atau karier. Perempuan mampu menjalankan berbagai peran yang dilakukan oleh lakilaki. Hal ini menampakkan bahwa adanya kesetaraaan antara perempuan dengan laki-laki.

Adegan memperlihatkan anak perempuan yang berpenampilan seperti anak lakilaki, bergulat melawan pegulat laki-laki yang berbadan kekar/atletis. Meskipun lawannya pegulat laki-laki, perempuan terlihat memberikan perlawanan yang baik. Artinya, perlawanan yang diberikan sesuai dengan aturan main dan dilakukan dengan adil tanpa memihak. Terlihat perempuan berhasil menjatuhkan badan lawan dan mencetak poin. Ini membuktikan bahwa perempuan sama kuatnya dengan pria. Hal ini didukung oleh Steven (2018), ia memaparkan, peran perempuan dapat disetarakan dengan laki-laki. Perempuan mampu menjalankan berbagai peran yang dilakukan oleh laki-laki. Hal ini menampakkan bahwa adanya kesetaraaan antara perempuan dengan laki-laki.

Representasi perempuan yang dapat disimpulkan dari film Dangal, yaitu adanya pengaruh yang terjadi pada masyarakat di India pada saat perempuan melakukan olahraga gulat yang mayoritas dilakukan laki-laki. Pengaruhnya antara lain, terjadinya perubahan pandangan tentang perempuan yang semula dianggap lemah dan hanya bisa mengerjakan pekerjaan domestik, serta perempuan juga mampu berprestasi dalam bidang olahrgara. Terlepas dari itu, ada pula bagian yang menunjukkan sosok ayah yang patriarkal dan cenderung chauvinisme (cinta kepada tanah air secara berlebih). Karena rasa ingin membuat bangga negara India (dibidang gulat) yang berlebihan, membuat putri-putrinya harus menjalankan latihan gulat sedari kecil.

\section{Simpulan}

Berdasarkan penelitian dan analisis yang telah dilakukan penulis, melalui beberapa adegan yang dipilih penulis dari film Dangal, dapat ditarik kesimpulan bahwa dalam film ini, pesan representasi perempuan begitu terlihat pada penokohan karakter perempuan, yaitu dari aksi para perempuan pada adegan-adegan di film. Representasi perempuan pada karakter yang ada dalam film Dangal ini mengalami perubahan. Tokoh utama Geeta dan Babita, merepresentasikan perempuan melalui pendalaman karakternya sebagai seorang pegulat yang melakukan olahraga pria. Pada film, awalnya perempuan direpresentasikan sebagai sosok yang lemah dan kodratnya hanya dijodohkan, dinikahkan dan ditugaskan untuk mengerjakan pekerjaan domestik. Namun, hal itu berubah saat tokoh Geeta dan Babita mampu bersaing dan mengalahkan laki-laki pada turnamen gulat. Perempuan kini dipandang memiliki kekuatan, keberanian, dan hak yang sama dengan laki-laki. Pesan representasi perempuan yang disampaikan, secara garis besar merujuk pada teori feminisme liberal yang menjunjung kesamaan perempuan dengan laki-laki, bahwa perempuan memiliki peran penting di dunia bukan saja dalam ruang lingkup domestik. 
Myesha Adira, Wulan Purnama Sari: Representasi Perempuan dalam Film Dangal Karya Disney dan Aamir Khan Productions

\section{Ucapan Terima Kasih}

Penulis mengucapkan terima kasih serta penghargaan sebanyak-banyaknya kepada semua pihak yang ikut berkontribusi pada penelitian ini terutama kepada Ibu Wulan Purnama Sari selaku pembimbing yang telah membantu penulis selama proses penelitian ini berlangsung. Serta kepada teman-teman yang telah membantu dan memberikan semangat kepada penulis.

\section{Daftar Pustaka}

Djunina, Herlyn. (2014). Representasi Perempuan Dalam Surat Kabar Analisis Wacana Kritis Rubrik Tapale'uk Di Surat Kabar Harian Pos Kupang Edisi Hari Kartini Sejak Tahun 2008 Hingga 2012. Kupang: Politeknik Pertanian Negeri Kupang.

Dwiastono, Rivan. Gulat Putri Ubah Pradigma Sosial India. (7 Februari 2017).

Diakses pada 3 September 2018 pukul 05.15 WIB, dari VOA Sports: https://www.voaindonesia.com/a/gulat-putri-ubah-paradigma-sosialindia/3709055.html

Mahfudzi, Nazar El. Humanitarisme Kehidupan Sosial Perempuan di India Tahun 2013-2015. (23 April 2018). Diakses pada 12 Desember 2018 pukul 10:42

WIB, dari Kumparan: https://kumparan.com/nazar-el-mahfudzi/humanitarismekehidupan-sosial-perempuan-di-india-tahun-2013-2015

Riswandi. (2009). Ilmu Komunikasi. Yogyakarta: Graha Ilmu.

Rohim, Syaiful. (2016). Teori Komunikasi: Perspektif, Ragam, dan Aplikasi. Jakarta: PT Rineka Cipta.

Romli, Khomsahrial. (2016). Komunikasi Massa. Jakarta: PT Grasindo.

Simanjuntak, Asnika Putri. (2018). Perempuan Masa Kini. Dalam Basri (Penyunting), Chapter: Srikandi Menerjang Ombak: Terjebak, Terhempas, Terdampar. Sulawesi: Mahasiswa Berpendidikan Hukum (MBH).

Sobur, Alex. (2013). Semiotika Komunikasi. Bandung: PT Remaja Rosdakarya.

Steven, Markus Hariadi. (2018). Perempuan Masa Kini. Dalam Basri. (Penyunting), Chapter: Ketertindasan Baru Wanita Karier (Telaah Berdasarkan Teori Simone De Beavoir). Sulawesi: Mahasiswa Berpendidikan Hukum (MBH).

Utaminingsih, Alifiulahtin. (2017). Gender dan Wanita Karir. Malang: Universitas Brawijaya Press.

Wibowo, Indiwan Seto Wahyu. (2011). Semiotika Komunikasi-Aplikasi Praktis bagi Penelitian dan Skripsi Komunikasi. Jakarta: Mitra Wacana Media.

Yuliyanti, Friska Dewi; Bajari, Atwar, Mulyana, Slamet. (2017). Representasi Maskulinitas Dalam Iklan Televisi Pond's Men \#Lelakimasakini (Analisis

Semiotika Roland Barthes Terhadap Representasi Maskulinitas). Bandung: Universitas Padjajaran. 